OPEN ACCESS

Edited by: Yoav Bashan,

The Bashan Institute of Science, USA

Reviewed by:

Kathleen Scott,

University of South Florida, USA

Qiang Wang,

Chinese Academy of Sciences, China

${ }^{*}$ Correspondence:

Eneko Ganuza

enekoganuza@gmail.com

Specialty section:

This article was submitted to

Aquatic Microbiology,

a section of the journal

Frontiers in Microbiology

Received: 01 February 2016 Accepted: 22 May 2016

Published: 20 June 2016

Citation:

Ganuza E, Sellers CE, Bennett BW,

Lyons EM and Carney LT (2016)

A Novel Treatment Protects Chlorella at Commercial Scale from the Predatory Bacterium Vampirovibrio chlorellavorus. Front. Microbiol. 7:848. doi: 10.3389/fmicb.2016.00848

\section{A Novel Treatment Protects Chlorella at Commercial Scale from the Predatory Bacterium Vampirovibrio chlorellavorus}

\author{
Eneko Ganuza ${ }^{1 *}$, Charles E. Sellers ${ }^{1}$, Braden W. Bennett ${ }^{2}$, Eric M. Lyons ${ }^{1}$ and \\ Laura T. Carney ${ }^{2}$
}

${ }^{1}$ Microbiology Group, Heliae Development, LLC, Gillbert, AZ, USA, ${ }^{2}$ Molecular Ecology Group, Heliae Development, LLC, Gilbert, AZ, USA

The predatory bacterium, Vampirovibrio chlorellavorus, can destroy a Chlorella culture in just a few days, rendering an otherwise robust algal crop into a discolored suspension of empty cell walls. Chlorella is used as a benchmark for open pond cultivation due to its fast growth. In nature, $V$. chlorellavorus plays an ecological role by controlling this widespread terrestrial and freshwater microalga, but it can have a devastating effect when it attacks large commercial ponds. We discovered that $V$. chlorellavorus was associated with the collapse of four pilot commercial-scale $(130,000 \mathrm{~L}$ volume) openpond reactors. Routine microscopy revealed the distinctive pattern of $V$. chlorellavorus attachment to the algal cells, followed by algal cell clumping, culture discoloration and ultimately, growth decline. The "crash" of the algal culture coincided with increasing proportions of $16 \mathrm{~s}$ rRNA sequencing reads assigned to $V$. chlorellavorus. We designed a qPCR assay to predict an impending culture crash and developed a novel treatment to control the bacterium. We found that (1) Chlorella growth was not affected by a 15 min exposure to $\mathrm{pH} 3.5$ in the presence of $0.5 \mathrm{~g} / \mathrm{L}$ acetate, when titrated with hydrochloric acid and (2) this treatment had a bactericidal effect on the culture (2-log decrease in aerobic counts). Therefore, when $\mathrm{APCR}$ results indicated a rise in $\mathrm{V}$. chlorellavorus amplicons, we found that the $\mathrm{pH}$-shock treatment prevented the culture crash and doubled the productive longevity of the culture. Furthermore, the treatment could be repeatedly applied to the same culture, at the beginning of at least two sequential batch cycles. In this case, the treatment was applied preventively, further increasing the longevity of the open pond culture. In summary, the treatment reversed the infection of $V$. chlorellavorus as confirmed by observations of bacterial attachment to Chlorella cells and by detection of $V$. chlorellavorus by 16 s rRNA sequencing and qPCR assay. The $\mathrm{pH}$-shock treatment is highly selective against prokaryotes, and it is a cost-effective treatment that can be used throughout the scale up and production process. To our knowledge, the treatment described here is the first effective control of $V$. chlorellavorus and will be an important tool for the microalgal industry and biofuel research.

Keywords: algae industry, Chlorella, crop protection, Micractinium inermum, pH-shock, predatory bacterium, Vampirovibrio chlorellavorus 


\section{INTRODUCTION}

Vampirovibrio chlorellavorus is a non-photosynthetic cyanobacterium (Melainabacteria; Soo et al., 2014) with a predatory lifestyle that targets a variety of Chlorella species (Coder and Starr, 1978). This predator only feeds on living algae cells and is unable to grow in liquid or agar media unless co-cultured with the alga. Electron microscopy-based studies (Coder and Goff, 1986; Mamkaeva and Rybal'chenko, 1979) have shown that $V$. chlorellavorus uses a flagellum to reach its prey and attach to the surface of the alga through fibril appendages. The attached cells remain epibiotic contrary to other predatory bacteria belonging to Bdellovibrio or Daptobacter (Guerrero et al., 1986). The unique predation mechanisms of $V$. chlorellavorous are exquisitely regulated. The bacterial cell secretes a path that connects with the alga, breaches through the parent cell wall and if necessary also through the daughter cell wall (Coder and Goff, 1986). Recent metagenomic analyses suggest that plasmid DNA and hydrolytic enzymes are transferred to the prey cells via the T4SS secretion system where they apparently degrade the algal cell contents (Soo et al., 2015). As the Chlorella cell is digested, the color changes from dark green to yellow brown, and empty or "ghost" Chlorella cells accumulate in the culture. If left unabated, the majority of Chlorella cells are destroyed and the culture develops a granular texture due to progressive clumping of algal cells visible to the naked eye (Coder and Starr, 1978).

Early detection by optical microscopy is difficult due to the pleomorphic shape and the small size of $V$. chlorellavorus $\left(<1 \mu^{3}\right.$; ultramicrobacterium; Coder and Starr, 1978). Other bacterial epiphytes may be mistaken for $V$. chlorellavorus; however, the infection becomes more apparent with the rapid increase in the proportion of Chlorella cells with attached bacteria and the development of a clear zone that spreads through the infected cell from the site of attachment (Coder and Goff, 1986). Using electron microscopy, V. chlorellavorus was first described in freshwater samples from a reservoir in Ukraine (Gromov and Mamkaeva, 1972) and later in freshwater anuran amphibian ponds in Brighton, UK (Wong et al., 1994). However, traditional detection tools have failed to provide a definitive diagnosis, and it is likely that the incidence of $V$. chlorellavorous infection has been overlooked. For example, only a few original papers have been published since this predator was first described (Gromov and Mamkaeva, 1972). Recently, molecular tools have targeted this predator across diverse systems. For example, $V$. chlorellavorous was identified in soil samples from Anhui, China (Shi et al., 2015), in bovine rumen samples from Nagaland, India (Das et al., 2014) and from open pond cultures of Chlorella at three different universities in the southwestern USA which suffered repeated V. chlorellavorus infections (personal communication from Drs. P. Lammers, J. Brown, and M. Sommerfeld).

In recent years it has become apparent that algal crop protection is one of the most important challenges facing the algal industry (Carney and Lane, 2014; McBride et al., 2016). Chlorella was the first eukaryotic microalgae to be grown in pure culture (Beijerinck, 1890) and today it is arguably the most common alga grown by the microalgal industry. Its high productivity and robustness allows a wide range of applications including food, feed, fertilizer, wastewater remediation, $\mathrm{CO}_{2}$ capture, and biodiesel production (Safi et al., 2014). V. chlorellavorus attacks this alga whether it is growing photoautotrophically (Coder and Goff, 1986), heterotrophically (Wong et al., 1994), or as described here, mixotrophically. Therefore, the lack of treatment to control $V$. chlorellavorus is a major challenge for the industry. Here, we report the development of tools for early detection and treatment of $V$. chlorellavorous.

\section{MATERIALS AND METHODS}

\section{Chlorella Culture Conditions Identification of the Algae}

Chlorella HS26 was isolated from soil samples in the Sonoran Desert of Arizona, USA and privately deposited in the Culture Collection of Algae at the University of Cologne (Germany). Total genomic DNA was extracted and purified using the DNeasy Plant Mini Kit (Qiagen, Hilden Germany) and the nuclear-encoded rRNA-operon was amplified by polymerase chain reaction (PCR) using DreamTaq ${ }^{\mathrm{TM}}$ DNA Polymerase (Fermentas, St. Leon-Rot, Germany). The DNA was sequenced for 18S, ITS1, 5.8S, ITS2, 28 S regions using universal eukaryotic primers (see Marin et al., 2003; Marin, 2012). The following PCR protocol was used: an initial denaturation step $\left(95^{\circ} \mathrm{C}\right.$ for $180 \mathrm{~min}$ ) was followed by 30 cycles including denaturation $\left(95^{\circ} \mathrm{C}\right.$ for $45 \mathrm{~min})$, annealing $\left(55^{\circ} \mathrm{C}\right.$ for $\left.60 \mathrm{~min}\right)$, and elongation $\left(72^{\circ} \mathrm{C}\right.$ for $180 \mathrm{~min}$ ). PCR products which showed single clear bands by gel electrophoresis were purified using the Dynabeads M280 Streptavidin system (Holmberg et al., 2005). For sequencing the SequiTherm EXCEL II Long Read DNA Sequencing Kit (Biozym Diagnostik, Germany) and fluorochrome-labeled primer combinations were used. Two partial and overlapping sequences of each strand were read out with a LI-COR IR2 DNA Sequencer (LI-COR Biosciences, Lincoln, NE, USA) and assembled to the complete rDNA sequence using the program AlignIR $^{\mathrm{TM}} 2.0$ (LI-COR Biosciences, Lincoln, NE, USA). Sequences were aligned manually on the basis of conserved rRNA secondary structures using SeaView 4.3.0 software and only unambiguously aligned sequences were used for phylogenetic analysis. The sequences were compared with existing sequences on the NCBI GenBank database via BLAST. The closest BLAST hits had at least $99 \%$ similarity to Chlorella sp. NIES2171 (accession number AB731604) and Chlorella vulgaris CCAP/79 (FR865683), consequently the species was preliminary identified as Chlorella sp. HS26. It should be noted that recently, the two reference species were proposed as Micractinium inermum NIES2171 (Hoshina and Fujiwara, 2013) and Micractinium sp. CCAP 211/79 (Germond et al., 2013), respectively. The new sequences for the strain used in this work were deposited in the NCBI database under the accession number KU641127.

\section{Laboratory Culture Conditions}

Small-scale testing of Chlorella was performed in duplicate using baffled experimental Erlenmeyer flasks (100 ml volume), incubated at $25^{\circ} \mathrm{C}$, and shaken at $100 \mathrm{rpm}$. The cultures were inoculated at $10 \% \mathrm{v} / \mathrm{v}$ from an axenic 2-3-day-old exponentially 
growing autotrophic flask culture using BG-11 medium. The experimental flasks were illuminated with LED lights at an intensity of $100 \mu \mathrm{mol}$ photons $/ \mathrm{m} / \mathrm{s}$, and sodium acetate trihydrate $(2.5 \mathrm{~g} / \mathrm{L})$ was added daily to support mixotrophic conditions. The $\mathrm{pH}$ was maintained between 7 and 8 , and the flasks were maintained in a $\mathrm{CO}_{2}$ enriched (2\%) atmosphere inside a chamber. For each flask experiment, we tested for a treatment effect, a time effect, and a treatment by time interactions using linear mixed models. Treatment and time were modeled as fixed effects, and we included a first-order autoregressive error structure (AR1) to account for temporally autocorrelated measures. Models were fit using the package lme4 (Bates et al., 2015) in R version 3.0.2 (R Core Team, 2016).

\section{Open Pond Culture Conditions}

The $\mathrm{pH}$ treatment validation was performed outdoors in open pond raceways (1000 L running volume) measuring $3.5 \mathrm{~m}$ long, $1.75 \mathrm{~m}$ wide and $19 \pm 1 \mathrm{~cm}$ depth cultures. The mixotrophic cultures were fed acetic acid on demand through a $\mathrm{pH}$-auxostat feedback control system. The culture was maintained at $\mathrm{pH}$ $7.4 \pm 0.05$ and residual acetic acid $(0.2-1 \mathrm{~g} / \mathrm{L})$ and nitrate $(0.2-$ $0.5 \mathrm{~g} / \mathrm{L})$ were maintained at constant concentrations throughout the batch cycle using a feedstock solution of acetic acid $(40 \% \mathrm{v} / \mathrm{v})$ and $\mathrm{NaNO}_{3}(40 \mathrm{~g} / \mathrm{L})$ as titrants. The initial BG-11 medium was modified to contain (in g/L): sodium acetate (0.5), NaNO3 (0.5), $\mathrm{K}_{2} \mathrm{HPO}_{4} 3 \mathrm{H}_{2} \mathrm{O}(0.04), \mathrm{MgSO}_{4} 7 \mathrm{H}_{2} \mathrm{O}$ (0.075), $\mathrm{CaCl} 2 \mathrm{H}_{2} \mathrm{O}(0.036)$, citric acid (0.006), ferric ammonium citrate (0.006), $\mathrm{MgNa}_{2}$ EDTA $\mathrm{H}_{2} \mathrm{O}(0.001)$, and $1 \mathrm{ml} / \mathrm{L}$ of a trace metal solution. The trace metal solution contained (in g/L): $\mathrm{H}_{3} \mathrm{BO}_{3}$ (2.86), $\mathrm{MnCl}_{2} 4 \mathrm{H}_{2} \mathrm{O}$ (1.81),

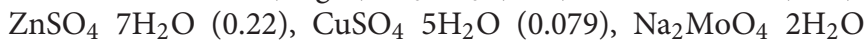
(0.391), $\mathrm{Co}\left(\mathrm{NO}_{3}\right)_{2} 6 \mathrm{H}_{2} \mathrm{O}(0.0494)$. The medium was prepared using reverse osmosis water and initial $\mathrm{pH}$ was corrected to 7.5 using $\mathrm{HCl}(1 \mathrm{M})$. The raceways were inoculated with $10 \%$ $\mathrm{v} / \mathrm{v}$ of outdoor open cultures that had previously been exposed to Vampirovibrio chlorellavorus. Temperature was maintained at $24 \pm 2^{\circ} \mathrm{C}$ using a $6 \mathrm{~m}$ long stainless steel heat exchange coil. Mixing was applied with a paddlewheel at $1 \mathrm{~m} / \mathrm{s}$ tip speed. The cultures were aerated ( $0.05 \mathrm{vol}$ air/vol culture per min) using a $6 \mathrm{~m}$ long porous hose and evaporation was corrected daily using reverse osmosis water. Culture conditions above were scaled up to a pilot $(60,000 \mathrm{~L})$ and commercial reactor $(130,000 \mathrm{~L})$ according to (Tonkovich et al., 2014, International Patent No 2014/144270 A1).

\section{Growth Assessment Cell Dry Weight}

Cell dry weight samples $(10 \mathrm{ml})$ were collected in duplicates daily from the cultures and vacuum filtered with glass microfiber filter papers designed to retain particles of $1.1 \mu \mathrm{m}$ (Ahlstrom ${ }^{\mathrm{TM}}$ Grade 161). The filtrate was washed twice with $10 \mathrm{ml}$ of ammonium bicarbonate $0.5 \mathrm{M}$ solution and placed in an oven $\left(105^{\circ} \mathrm{C}\right)$ until weight was stable.

\section{Residual Nutrients}

Culture samples $(2 \mathrm{~mL})$ were centrifuged $(17,000 \times g$ for $7 \mathrm{~min})$ and the supernatant was removed and diluted 20 -fold. Acetate in the medium was analyzed by HPLC according to the Association of Official Agricultural Chemists Official Method 986.13. The nitrates were analyzed using a Latchat Quickchem ${ }^{\mathrm{TM}} 8500$ and the UV-method 10049 (Hach, Milwaukee, WI, USA).

\section{Culture Longevity}

Culture longevity of Chlorella was determined based on the total productive days in the target reactor. Chlorella cultures operated in sequential batch cycles. The new batch started from the previous batch before this reached stationary phase. Thus, those days with stable or declining dry weights indicated the end of the life of that culture and were excluded from the longevity calculations. The longevity within our commercial reactors $(130,000 \mathrm{~L})$ was compared between treated $(n=9)$ and untreated $(n=8)$ runs using a student's $t$-test $\left(\mathrm{JMP}^{\circledR}, \mathrm{Version}\right.$ 12.1 SAS Institute Inc., Cary, NC, USA).

\section{Contamination Assessment \\ Total Aerobic Bacterial Counts}

Total aerobic bacterial counts were determined in duplicates using $3 \mathrm{M}$ Petrifilm ${ }^{\mathrm{TM}}$ Aerobic Count Plates. The plates were incubated for 3 days at $35^{\circ} \mathrm{C}$ and counts were read using the $3 \mathrm{M}^{\mathrm{TM}}$ Petrifilm ${ }^{\mathrm{TM}}$ Plate Reader and associated image analysis software.

\section{The Percentage of Chlorella with Attached Bacteria}

The percentage of Chlorella with attached bacteria was determined with phase contrast light microscopy using oil immersion objective lens ( $100 \times$; Olympus DP72). Algal cells with one or more bacteria on their surface were recorded as positive infection. Overall, 50-100 algal cells were used to calculate the percentage. The standard deviation for the method was below $10 \%$.

\section{Determination of Bacterial Community Structure}

Samples $(2 \mathrm{~mL})$ were collected daily from outdoor Chlorella cultures and prepared for small subunit rDNA sequencing as follows. For total DNA extraction, the biomass was concentrated by centrifugation $(10,000 \times g$ for $10 \mathrm{~min})$ and DNA was purified using the ZR Fungal/Bacterial DNA mini prep kit (Zymo Research, Irvine, CA, USA). To isolate microbiome DNA that was only associated with the phycosphere, biomass was concentrated using slow speed centrifugation $(1000 \times g$ for $7 \mathrm{~min})$, the supernatant containing unattached bacteria was discarded, the pellet was washed by resuspension in sterile water three times, and the final pellet was collected using high speed centrifugation $(17,000 \times g$ for $7 \mathrm{~min})$. To isolate DNA from the whole culture portion, biomass was collected using high speed centrifugation $(17,000 \times g$ for $7 \mathrm{~min})$. For all samples, DNA purity and quantity was determined via 260/280 $\mathrm{nm}$ readings then normalized to $10 \mathrm{ng} / \mu \mathrm{L}$. PCR was conducted on the normalized gDNA using chloroplast excluding 16S rDNA primer set 799F/U1492R (Chelius and Triplett, 2001). The following PCR protocol was used: an initial denaturation step $\left(98^{\circ} \mathrm{C}\right.$ for $\left.30 \mathrm{~s}\right)$, followed by 35 cycles of denaturation $\left(98^{\circ} \mathrm{C}\right.$ for $\left.10 \mathrm{~s}\right)$, annealing $\left(53^{\circ} \mathrm{C}\right.$ for $\left.30 \mathrm{~s}\right)$ and elongation $\left(72^{\circ} \mathrm{C}\right.$ for $\left.60 \mathrm{~s}\right)$. The PCR cycle was ended with a $72^{\circ} \mathrm{C}$ final elongation for $10 \mathrm{~min}$. The resulting PCR product was visualized on agarose gels for confirmation of expected bands 
( $\sim 700 \mathrm{bp}$ ) and then cloned using Zero Blunt Topo PCR cloning kits (Invitrogen, Carlsbad, CA, USA). 16S rDNA clone library inserts were sequenced with the $\mathrm{T} 7$ vector primer using an $\mathrm{ABI}$ 3730xl DNA Analyzer.

The resulting $16 \mathrm{~S}$ rDNA sequences were aligned and trimmed of primer and vector sequences using the built-in trimming tool in the Geneious 8.1.5 software suite (Biomatters, Ltd, New Zealand) with vector trimming against the NCBI UniVec database $^{1}$. Sequences with an HQ \% quality score below $30 \%$ were excluded from analysis. Sequences were then aligned to the NCBI "nr" database for taxonomic assignment using BLAST (Altschul et al., 1990). Best BLAST hits had $\geq 98 \%$ similarity to the query sequence picked for taxonomic assignment. For verification of assignments, the trimmed sequences were also aligned and classified using the SINA online alignment tool against the SILVA 119 database [lc1] (Pruesse et al., 2012). Although these methods involved two different reference databases and alignment algorithms, the taxonomic assignments were in agreement at $>98-99 \%$ sequence similarity (data not shown).

${ }^{1} \mathrm{ftp}: / /$ ftp.ncbi.nlm.nih.gov/pub/UniVec/
Heatmaps of bacterial relative abundance were generated using the phyloseq R package (McMurdie and Holmes, 2013).

\section{Predator Identification and Tracking Using qPCR Assay}

A proprietary 6-carboxyfluorescein based (FAM) qPCR assay was designed for $V$. chlorellavorous consisting of forward and reverse primers and a species specific probe. The assay is not publically available at this time; however, the information may be made available by contacting Heliae and agreeing to confidentiality terms. The assay was designed using a clone insert bacterial 16S rRNA sequence from an infected pond (Accession number KU570459). The clone exhibited $>99 \%$ similarity (692/695 nucleotide match) to a GenBank $16 \mathrm{~S}$ gene sequence (Accession number HM038000) from the $V$. chlorellavorous type culture that was deposited by Coder and Starr (1978) and sequenced by the American Type Culture Collection (ATCC29753). DNA collected from the phycosphereenriched fraction of the same culture was used as a positive control template. Pond samples $(2 \mathrm{~mL})$ were lysed by bead beating using $0.5 \mathrm{~mm}$ beads at $3400 \mathrm{rpm}$ for $2 \mathrm{~min}$ and centrifuged at $10000 \times g$ for 1 min to remove cellular debris.

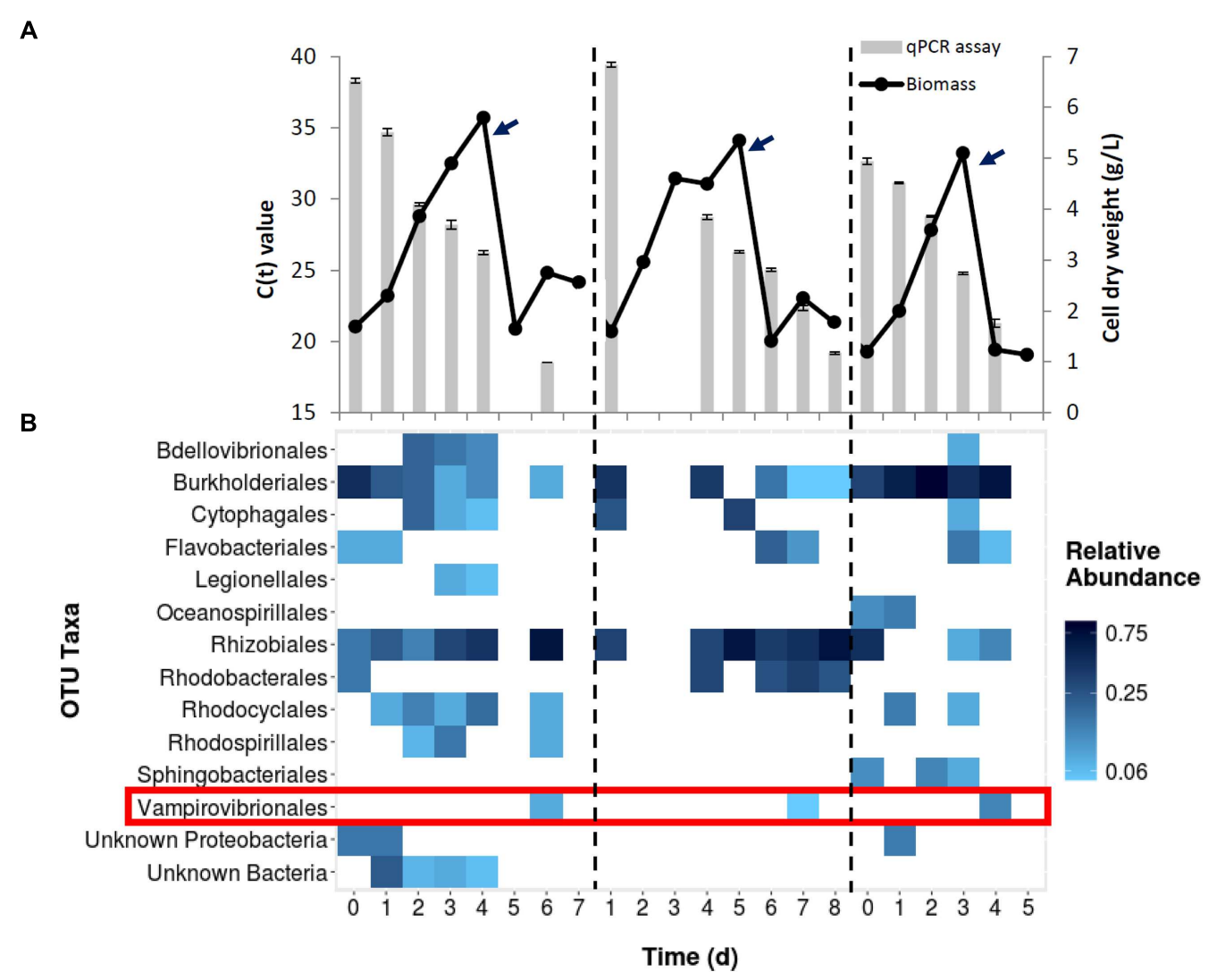

FIGURE 1 | (A) Growth of Chlorella culture during three different scale up cycles in outdoor mixotrophic commercial reactors. Each cycle (divided by the dash line) represents the seed production $(60,000 \mathrm{~L})$ and transfer (denoted by arrows) to a commercial-scale reactor (130,000 L volume). Bars represent Vampirovibrio chlorellavorus infection as detected by qPCR assay in each cycle. The $C_{t}$ value, or cycle threshold, decreases as the target abundance increases. (B) Bacterial community structure from whole culture samples of same three runs based on 16s rRNA gene sequencing. The detection of $V$. chlorellavorus sequences coincide with a decline or arrest in the growth of Chlorella shown in (A). 
The aqueous supernatant $(1 \mu \mathrm{L})$ from the lysate was used as a template for the $\mathrm{qPCR}$ assay in $10 \mathrm{uL}$ total volume reactions. The following $\mathrm{qPCR}$ protocol was used: an initial denaturation step $\left(98^{\circ} \mathrm{C}\right.$ for $\left.3 \mathrm{~min}\right)$, followed by 40 cycles of denaturation at $95^{\circ} \mathrm{C}$ for $5 \mathrm{~s}$, and annealing at $60^{\circ} \mathrm{C}$ for $30 \mathrm{~s}$. The total run time for the assay was $120 \mathrm{~min}$. The assay showed specificity only to the $V$. chlorellavorous assigned clone insert and tested negative $\left(C_{\mathrm{t}}=0\right)$ against purified $16 S$ sequences from various bacterial isolates representing multiple genera (Shewanella sp., Acinetobacter sp., Ochrobactrum sp., Pseudochrobactrum sp., Bacillus sp., Stenotrophomonas sp., Clostridium sp., Azospirillum sp., Gemmobacter sp., Pseudomonas

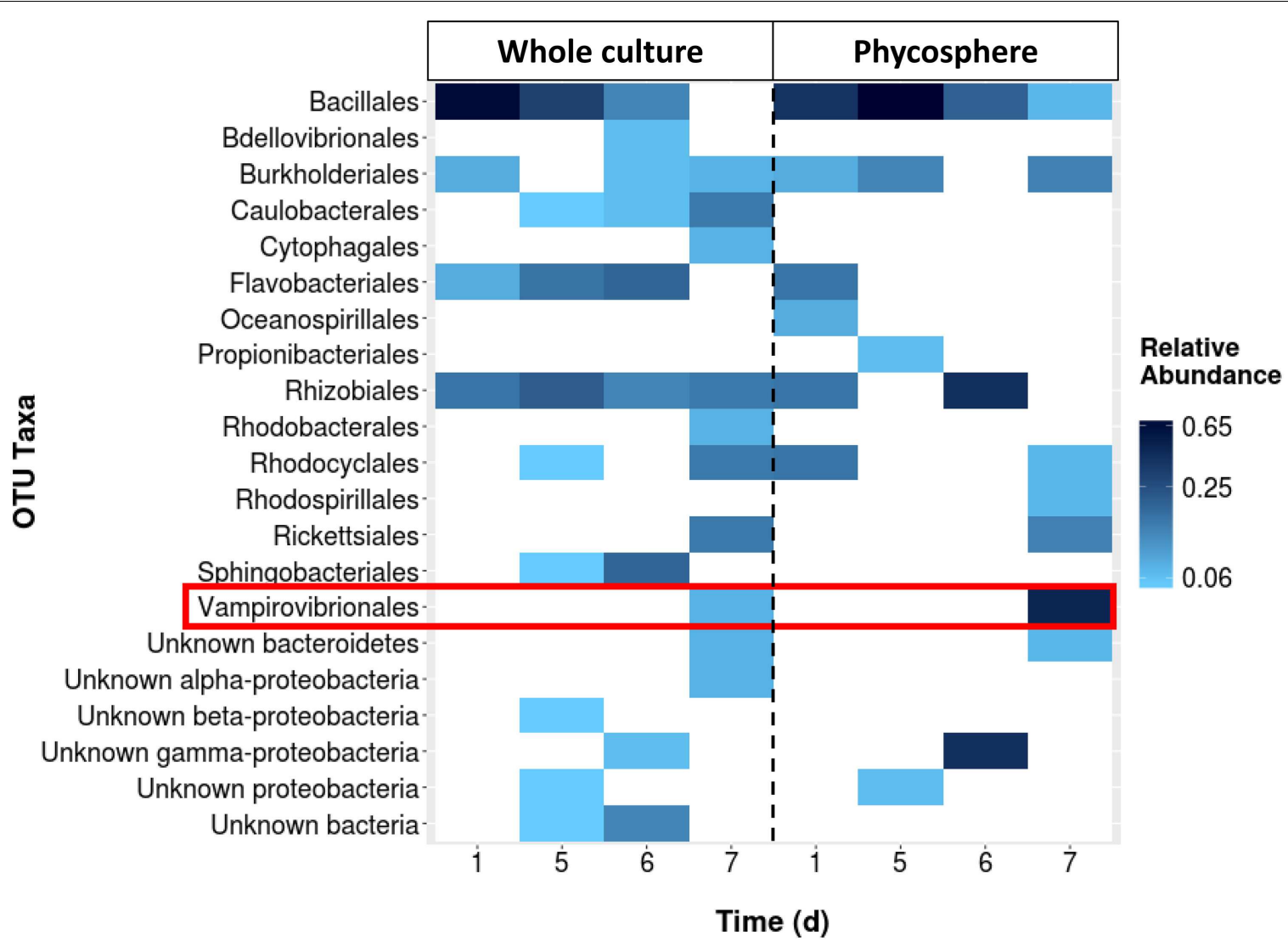

FIGURE 2 | The comparison between the whole culture bacterial community structure (16s rRNA gene sequencing assay) of a batch culture of Chlorella and the corresponding phycosphere portion. Sequencing data was not available for days $2-4$.

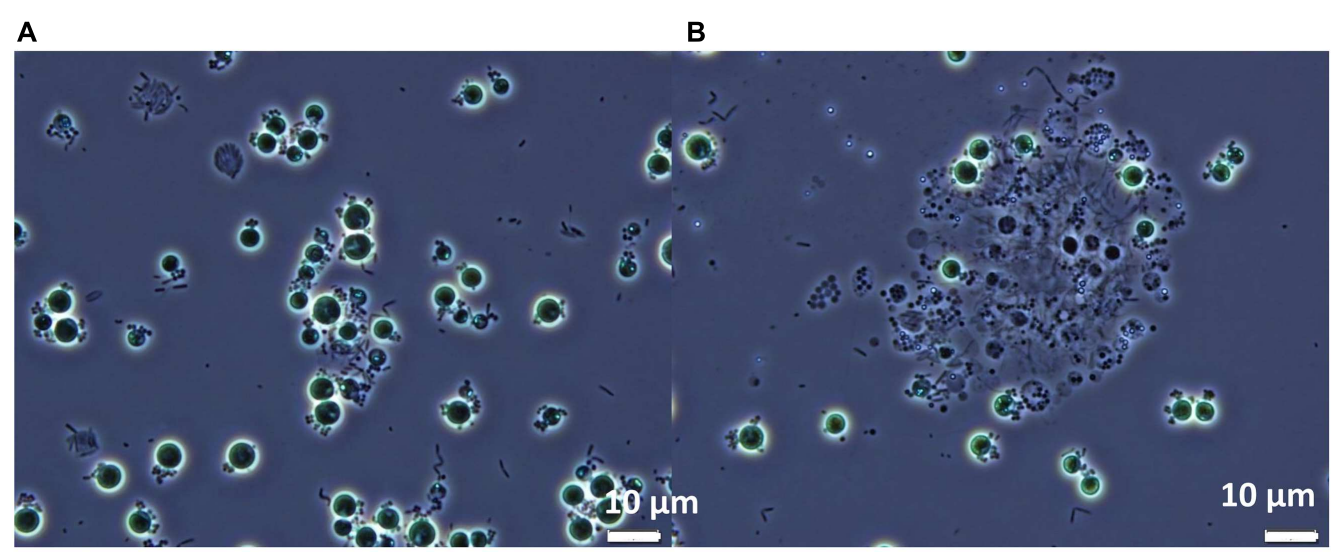

FIGURE 3 | Phase contrast micrographs of Chlorella commercial cultures heavily infested with Vampirovibrio-like cells at two different stages (A) Appearance of the first empty or ghost cells. (B) Culture clumping. Micrographs produced by R. A. Andersen. 
sp., Pedobacter sp., Pannonibacter sp., Rheinheimera sp. Azoarcus sp., Cloacibacterium sp., and Comamonas sp.).

\section{Predator Treatment Development Literature Review on Cytoplasmic pH Regulation by Microalgae}

Literature review on cytoplasmic $\mathrm{pH}$ regulation by microalgae was performed to compare the response of Cyanophyta and Chlorophyta to the medium $\mathrm{pH}$. The review included peerreviewed articles that analyzed the cytosolic $\mathrm{pH}$ of algae at two or more medium $\mathrm{pH}$ set points. Cytosolic $\mathrm{pH}$ was analyzed using either 5,5-dimethoxazolidine-2,4-dione (DMO), ${ }^{31} \mathrm{P}-\mathrm{NMR}$ spectroscopy, or fluorochrome methods. Mean $\mathrm{pH}$ values were easily transcribed either from a data table or a detailed line graph reported in those articles. Means and standard deviations were calculated based on data from 3 to 7 different strains. Acidophilic microalgae, with an optimum growth at a $\mathrm{pH}$ below 5, were excluded from this review. Most cyanobacteria stopped growing at medium $\mathrm{pH}$ below 6 and cytosolic $\mathrm{pH}$ data could not be retrieved for those data points.

\section{The pH-Shock Treatment}

The $\mathrm{pH}$-shock treatment was applied by adding hydrochloric acid $(\mathrm{HCl} ; 34 \% \mathrm{v} / \mathrm{v})$ to well mixed algae culture until the $\mathrm{pH}$ decreased from 7.5 to 3.5. The $\mathrm{pH}$ of the algae culture was maintained at $\mathrm{pH}$ 3.5 for $15 \mathrm{~min}$ in the presence of $0.5 \mathrm{~g} / \mathrm{L}$ residual acetate. The $\mathrm{pH}$ was then returned to $\mathrm{pH} 7.5$ using sodium hydroxide $(2 \mathrm{M})$. More details on the method and method variants are provided by Ganuza and Tonkovich (2015, U.S. Patent No 9,181,523).
A

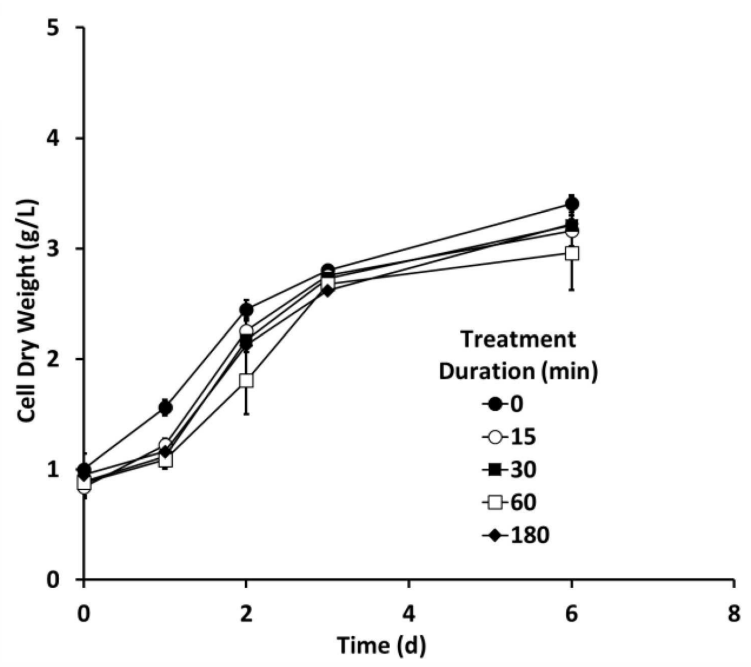

C

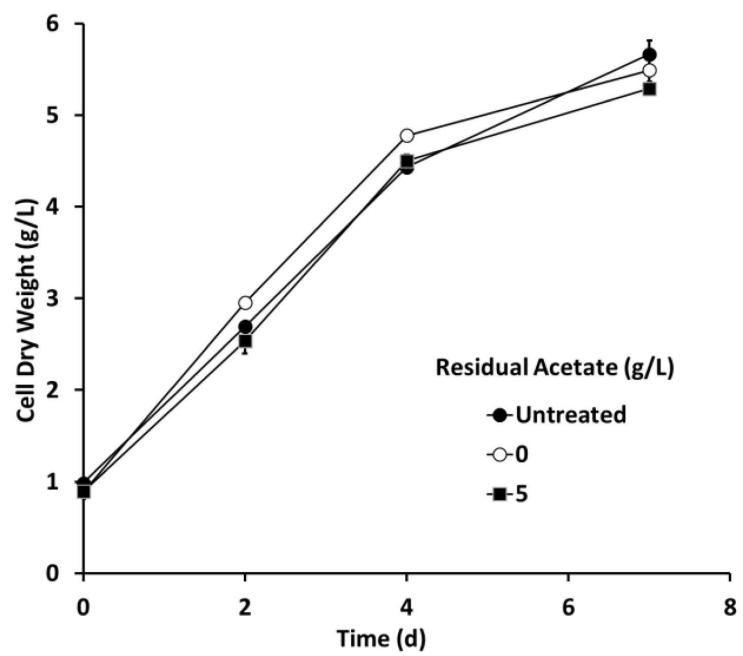

B

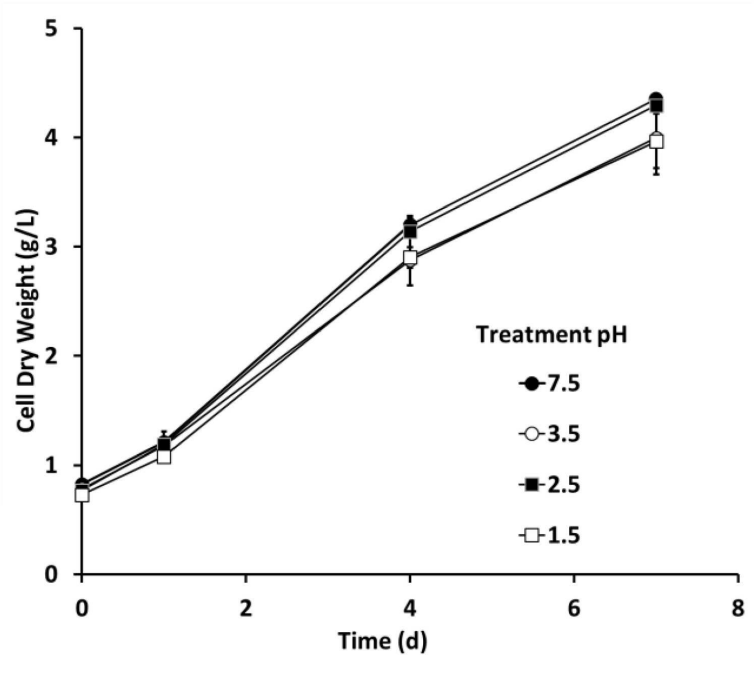

D

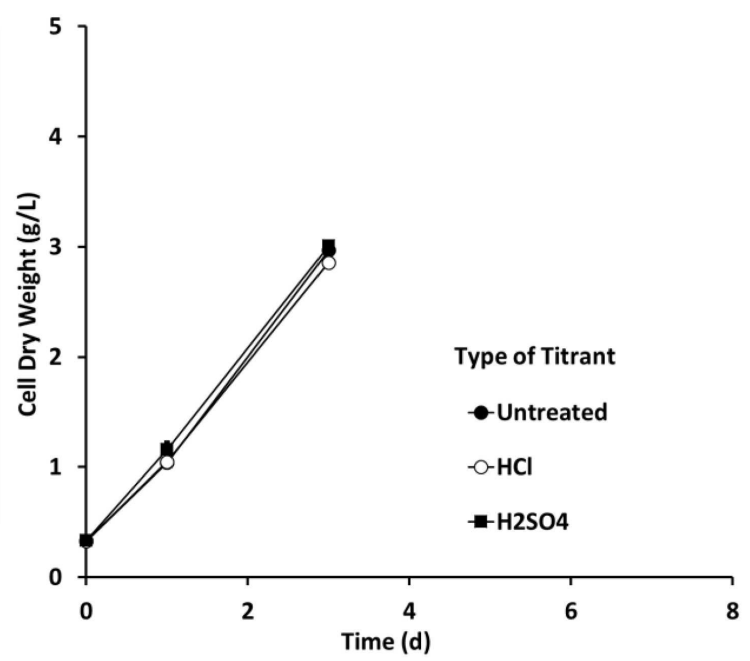

FIGURE 4 | The pH-shock treatment (A) duration, (B) pH level, (C) residual acetate concentration, and (D) type of titrant did not affect Chlorella growth in flasks $(\mathbf{2 5 0} \mathrm{mL}, \boldsymbol{n}=\mathbf{2})$. Unless stated otherwise the $\mathrm{pH}$ treatment was conducted using hydrochloric acid (HCL) to reduce $\mathrm{pH}$ to 3.5 for $15 \mathrm{~min}$ in the presence of $0.5 \mathrm{~g} / \mathrm{L}$ acetate and then inoculated aseptically into the Chlorella culture. Error bars represent 1 standard deviation. 


\section{RESULTS}

\section{Predator Identification}

Three data sets are presented as representative examples (Figure 1). Cultures grown in 60,000 L bioreactors showed initial Chlorella growth as measured by biomass increase. After transferring the cultures to the 130,000 L reactor (arrows; Figure 1A), biomass declined in 2-3 days. When identifying $V$. chlorellavorus using $16 \mathrm{~S}$ rRNA sequences, the bacterium was not detected until day 6 , at which time the culture was crashing. In addition to $V$. chlorellavorus, other bacterial taxa were present throughout the experiments (Figure 1B). When quantifying $V$. chlorellavorus using the qPCR assay the progress of the infection was observed in anticipation of the crashing of the culture (Figure 1A).
A fourth 130,000 L reactor was investigated using only 16S rRNA sequences and the proportion of $V$. chlorellavorus from the whole pond community was compared to the community associated with the phycosphere (Figure 2). While $V$. chlorellavorus was present in both whole pond and phycosphere samples on day 7 , the proportion of reads assigned to this predatory bacterium was much more abundant in the phycosphere sample ( 0.47 versus 0.07$)$.

When viewed microscopically, the Chlorella culture was heavily infested with Vampirovibrio-like cells (Figure 3). Initially, a single $V$. chlorellavorus cell attached to the outside of a Chlorella cell, but this quickly developed into a chain and then a cluster of bacterial cells. As the predation proceeded, numerous bacterial cells formed and then were released, eventually leaving empty or ghost algal cells (Figure 3A). Finally, as the predation

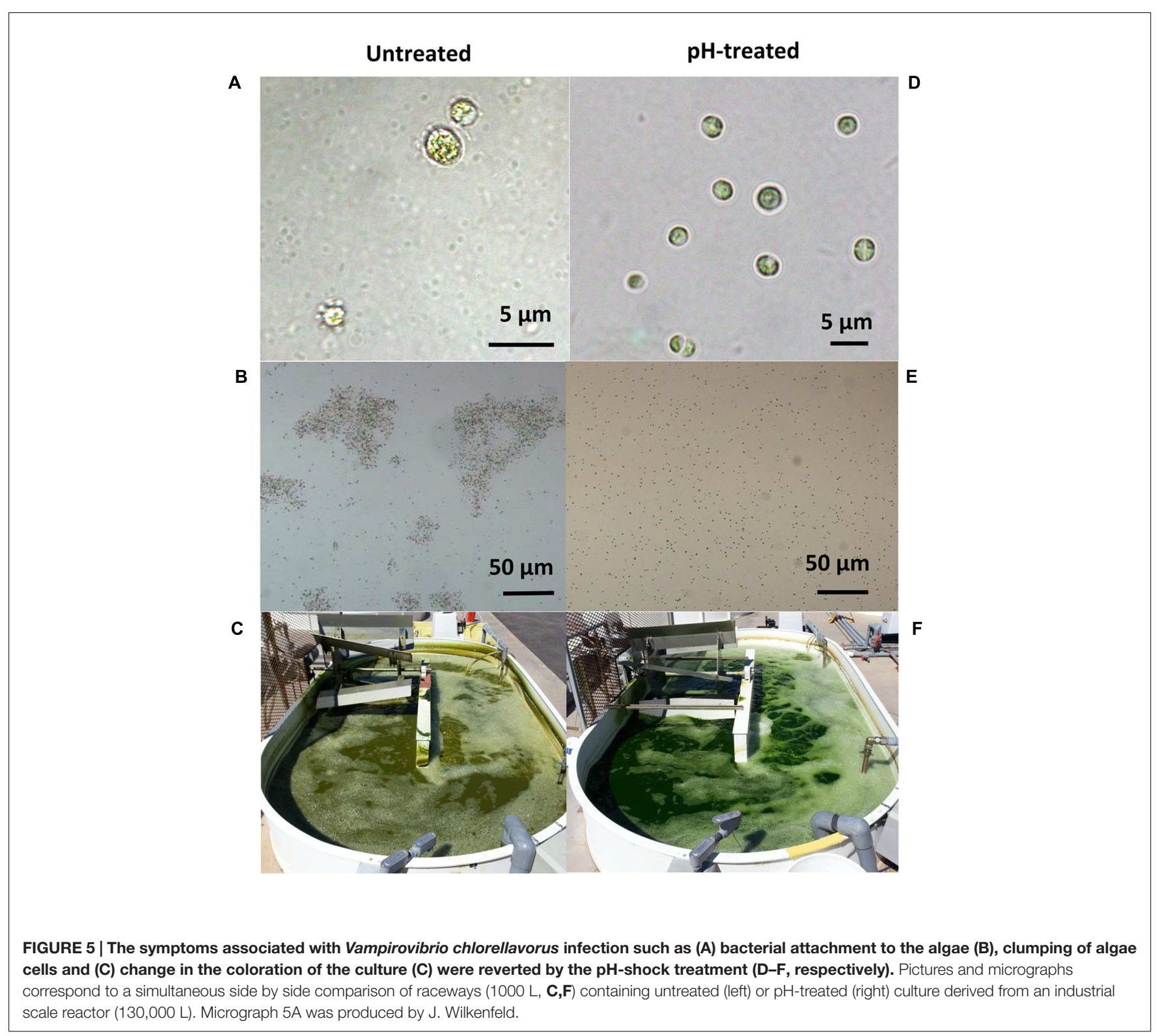


event neared completion, the Chlorella cells began clumping, apparently held together by a bacterial matrix (Figure 3B).

\section{Predator Treatment Development in Laboratory}

Preliminary flask experiments showed that Chlorella tolerated a $\mathrm{pH}$-shock ( $\mathrm{pH} 3.5$ ) up to at least $2 \mathrm{~h}$ (Figure 4A). Chlorella also tolerated a $15 \mathrm{~min} \mathrm{pH}$-shock as low as $\mathrm{pH}$ 1.5 (Figure 4B), and cells tolerated the $\mathrm{pH}$-shock even in the presence of up to $5 \mathrm{~g} / \mathrm{L}$ acetate (Figure 4C). Lastly, Chlorella tolerated treatments using either sulfuric acid or $\mathrm{HCls}$ as titrants (Figure 4D). No significant differences were observed between any of the treatments tested during these four experiments according to the Generalized Linear Model analysis $(P>0.1)$.

\section{Predator Treatment Development in Open Ponds}

Based on positive results from laboratory experiments, the $\mathrm{pH}$ shock treatment was tested outdoors on mixotrophic cultures growing in small raceways $(1000 \mathrm{~L})$. A contaminated culture $(70 \%$ Chlorella cells having attached bacteria) was removed from a large reactor $(130,000 \mathrm{~L})$ and used to inoculate two small raceways. One raceway was $\mathrm{pH}$-treated as follows: (1) the $\mathrm{pH}$ was decreased from 7.5 to 3.5 using $\mathrm{HCl},(2)$ the $\mathrm{pH}$ was maintained at $\mathrm{pH} 3.5$ for $15 \mathrm{~min}$ in the presence of $0.5 \mathrm{~g} \mathrm{~L}^{-1}$ residual acetate, and (3) the $\mathrm{pH}$ was then returned to $\mathrm{pH} 7.5$ using sodium hydroxide (Ganuza and Tonkovich, 2015, U.S. Patent No 9,181,523). The second raceway was left untreated. The visual symptoms associated with $V$. chlorellavorus predation (i.e., bacterial attachment to the algae, clumping of algae cells, and change in culture color)
A

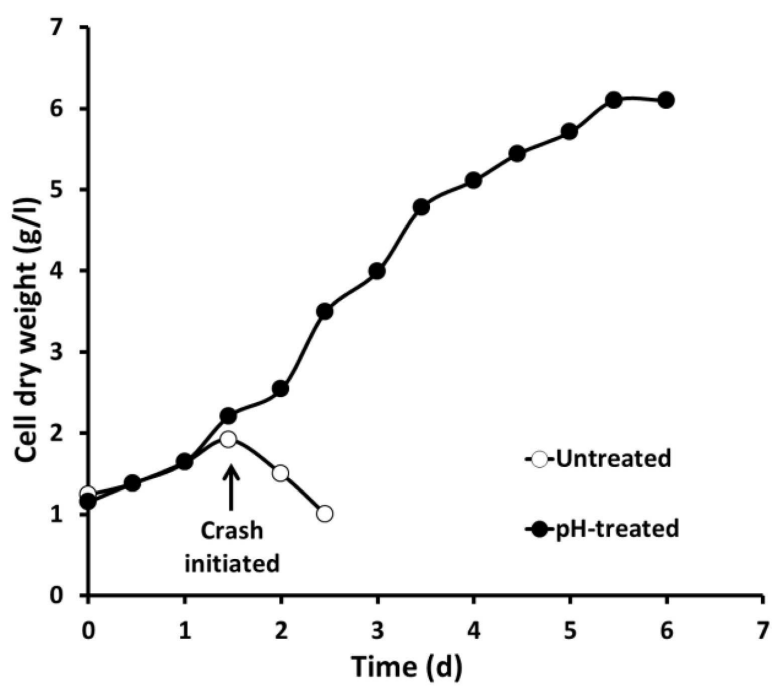

C

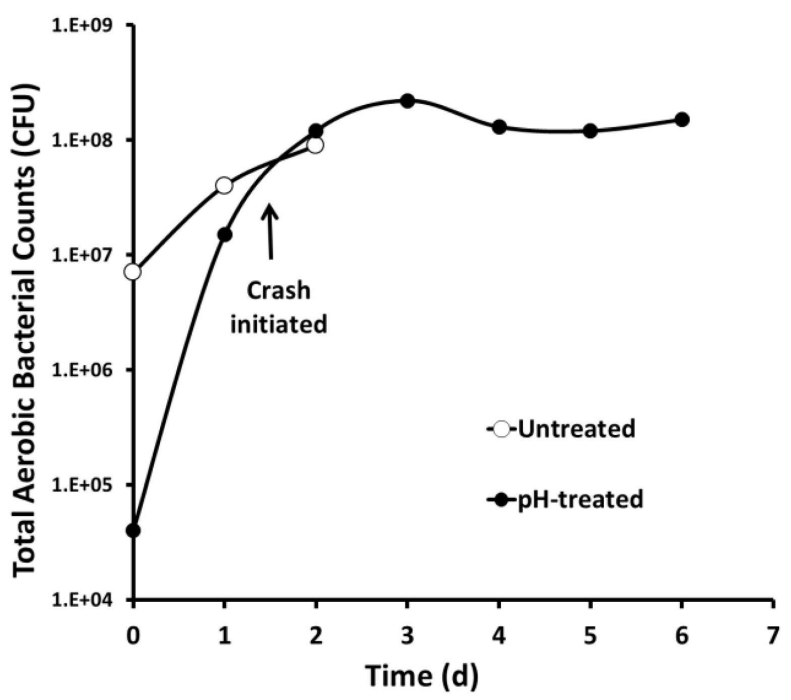

B

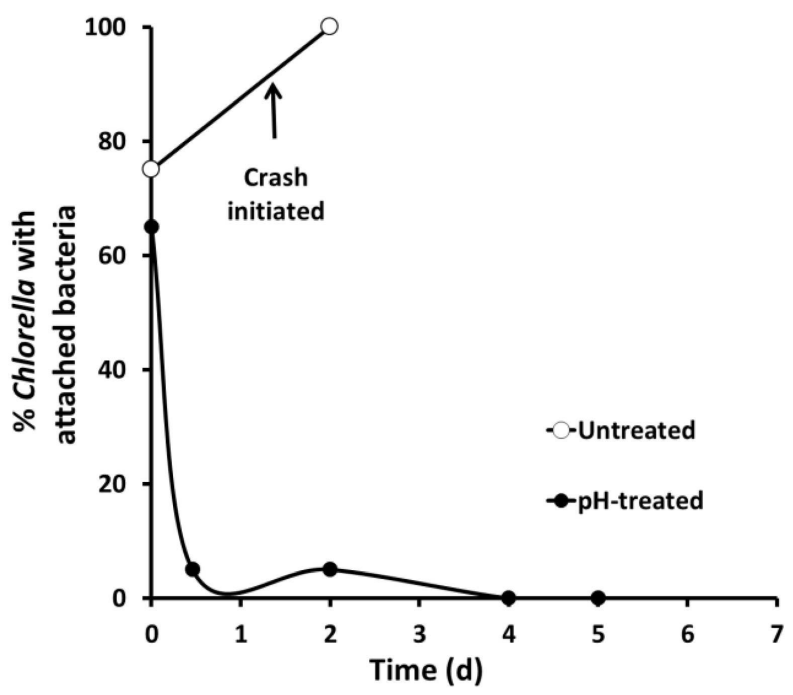

D

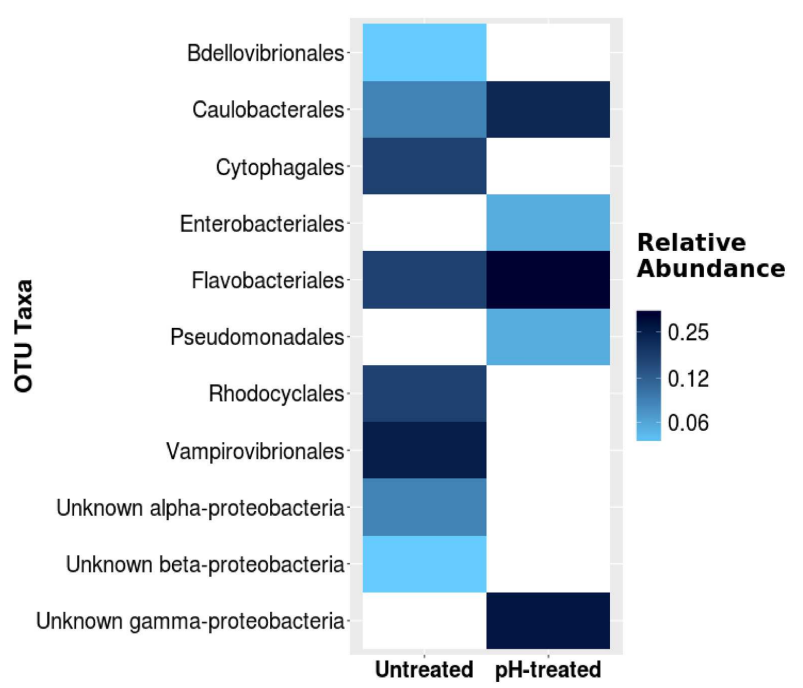

FIGURE 6 | The impact of pH-shock treatment (close circles) on (A) Chlorella growth (B) bacterial attachment to the algae phycosphere (C) total aerobic bacterial count and (D) 16s rRNA Vampirovibrio chlorellavorus sequencing. Data correspond to a simultaneous side by side comparison in raceways (1000 L, $n=1$ ) of $\mathrm{pH}$-treated and untreated culture originated from in an industrial scale reactor $(130,000 \mathrm{~L})$. 
were only observed in the untreated raceway (Figures 5AC), and this culture crashed within 2 days. In the $\mathrm{pH}$ treated culture, the symptoms of infection were reversed and a culture crash was prevented (Figures 5D-F). The $\mathrm{pH}$-treated culture remained healthy, reaching a cell density of $6 \mathrm{~g} / \mathrm{L}$ within 6 days (Figure 6A). Bacterial attachment to the algal cells was reversed and eliminated within $12 \mathrm{~h}$ of treatment (Figure 6B) and a twolog decrease in total aerobic plate counts (day 0 , treated vs. untreated) demonstrated the bactericidal effect of the treatment (Figure 6C). Analyses based on16s rRNA sequencing showed suggested that the $\mathrm{pH}$ treatment was effective at eliminating $V$. chlorellavorus, i.e., V. chlorellavorus reads were not detected in the $\mathrm{pH}$-treated reactor 2 days after treatment but $V$. chlorellavorus comprised $25 \%$ of the bacterial community in the untreated reactor (Figure 6D).

A second outdoor $\mathrm{pH}$ treatment experiment used the more sensitive and timely qPCR analysis to track infection (Figure 7). A mildly contaminated culture (20\% bacterial attachment) removed from an open pond raceway (1000 L) was used to inoculate two additional $1000 \mathrm{~L}$ raceways that were operating mixotrophically. One raceway was left untreated while the other received a $\mathrm{pH}$-shock treatment. Bacterial attachment in the untreated reactor dramatically increased to $100 \%$ within 3 days and cell dry weight declined and crashed within 3-5 days (Figures 7A,B). These changes followed an increase in detection of $V$. chlorellavorus in the untreated

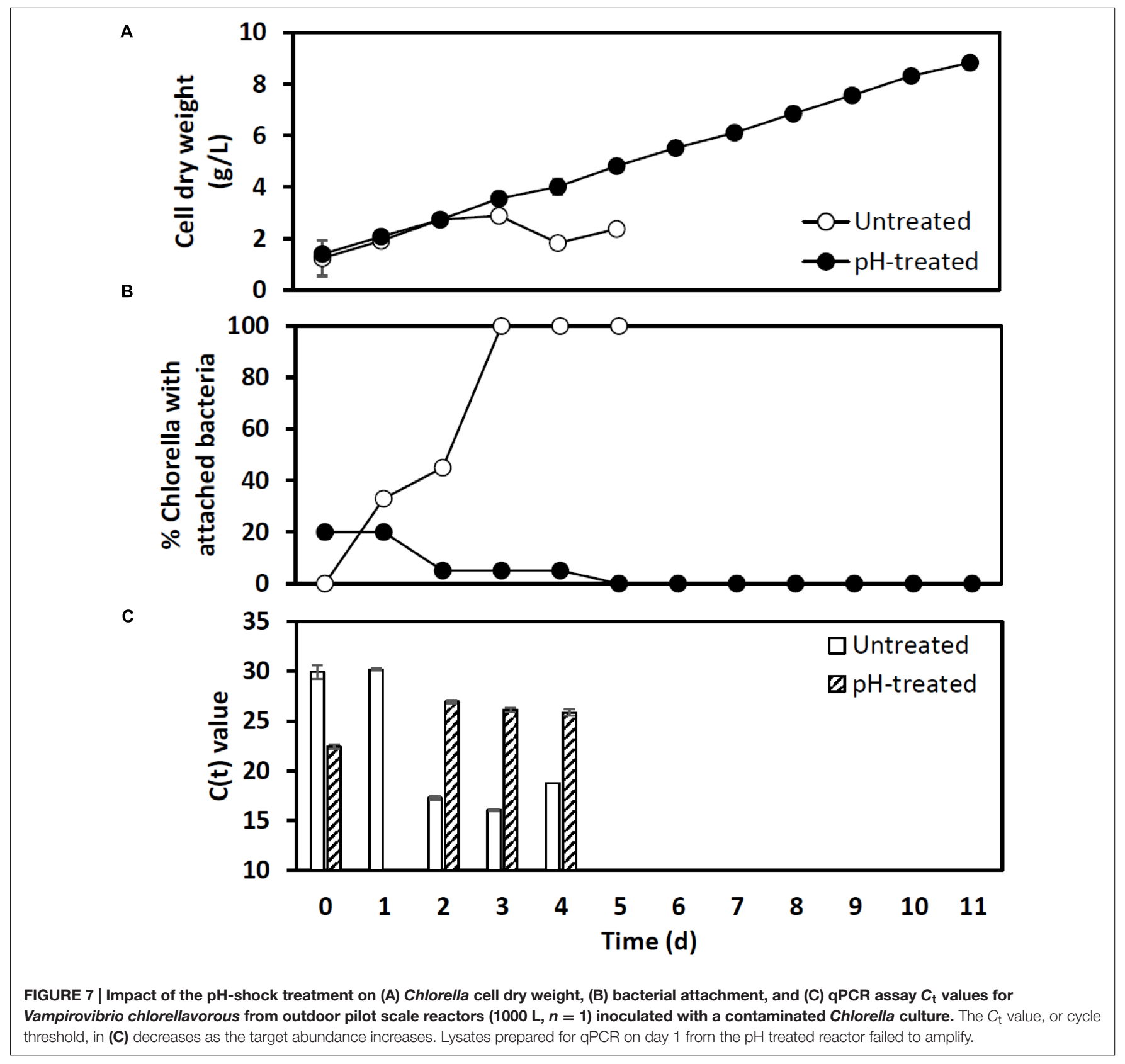


reactor via qPCR on day 2 when attachment was at $40 \%$ (Figure 7B). If this had been a single commercial scale reactor run, qPCR would have provided a 3-day warning that the culture was headed for a crash and crop protection strategies could have been initiated. $V$. chlorellavorus detection in the $\mathrm{pH}$-treated culture remained stable, while attachment was reduced to $5 \%$ and cell dry weights continued to increase for 11 days to $8.5 \mathrm{~g} / \mathrm{L}$ (Figure 7). This response confirmed the efficacy of the $\mathrm{pH}$ treatment against this previously fatal $V$. chlorellavorus predator in outdoor ponds used to grow Chlorella.

To date, we have confirmed the efficacy of the $\mathrm{pH}$-shock treatment at commercial-scale (130,000 L running volume) during nine additional reactor runs that were compared to untreated control cultures. The longevity of the $\mathrm{pH}$ treated ponds (12.7 \pm 2.7 days [mean \pm 1 SD]) was significantly higher ( $t$-test; $t(1)=4.47, P<0.01)$ than the longevity of the untreated ponds $(7.0 \pm 2.7$ days [mean $\pm 1 \mathrm{SD}])$, increasing the total harvested biomass. Additionally, we found that for a typical batch operation involving scaling up and transferring cultures every 6 days between outdoor reactors, Chlorella could be treated right before transfer for at least two sequential transfers; this treatment schedule resulted in an increased culture longevity from eight to over twenty consecutive days (Figure 8).

\section{DISCUSSION}

Microalgae are among the few species in industrial microbiology that are grown in open ponds. Consequently, as in agriculture, crop protection is one of the most important challenges facing the microalgal industry, and it has been recognized as a chief limiting factor for microalgal production at commercial scale (Carney and Lane, 2014; McBride et al., 2016). Previously, pests encountered in commercial microalgal systems were

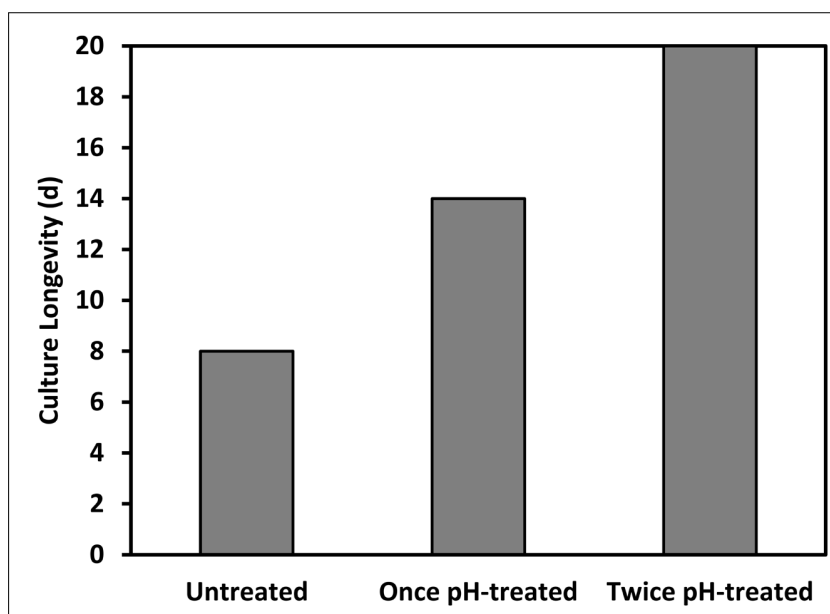

FIGURE 8 | Longevity of a Chlorella culture was prolonged by applying the $\mathrm{pH}$ treatment repeatedly to the same culture upon transfer, at the beginning of at least two consecutive batch cycles. not widely reported, and even minimized in an effort to make the microalgal industry appear more promising. Today, a diverse assemblage of zooplankton, fungi, bacteria, and viruses are known to attack microalgal cultures, and their impacts range from chronically reduced production to swift and irreversible culture crashes (Carney et al., 2014; Gong et al., 2015; Touloupakis et al., 2015; White and Ryan, 2015). Despite a more open acknowledgment of pests and the more frequent use of molecular diagnostic techniques for predator and pathogen detection (Carney et al., 2016), there are still very few detailed descriptions of crop protection strategies. Reports of treatments have included commercial fungicides (McBride et al., 2014) and hydrogen peroxide (Carney and Sorensen, 2015, U.S. Patent No 9,113,607) for fungal pathogens, $\mathrm{pH}$ transitions for rotifers (Zmora and Richmond, 2004), hyperchlorite (Zmora and Richmond, 2004), and size selective pulsed electric fields (Rego et al., 2015) for protozoa; see McBride et al. (2016) for a detailed review of reactive and preventative strategies.

Our study identified the causative organism that was apparently impacting our commercial Chlorella ponds. During infection, a larger proportion of $V$. chlorellavorous sequence reads were present in the region immediately surrounding the algal cells (i.e., the phycosphere) compared to bacteria freeliving in the supernatant (Figure 2). This observation is in agreement with reports describing the epibiotic lifestyle of this predator (Coder and Star, 1978). Although V. chlorellavorous was originally identified as the potential causative crash agent

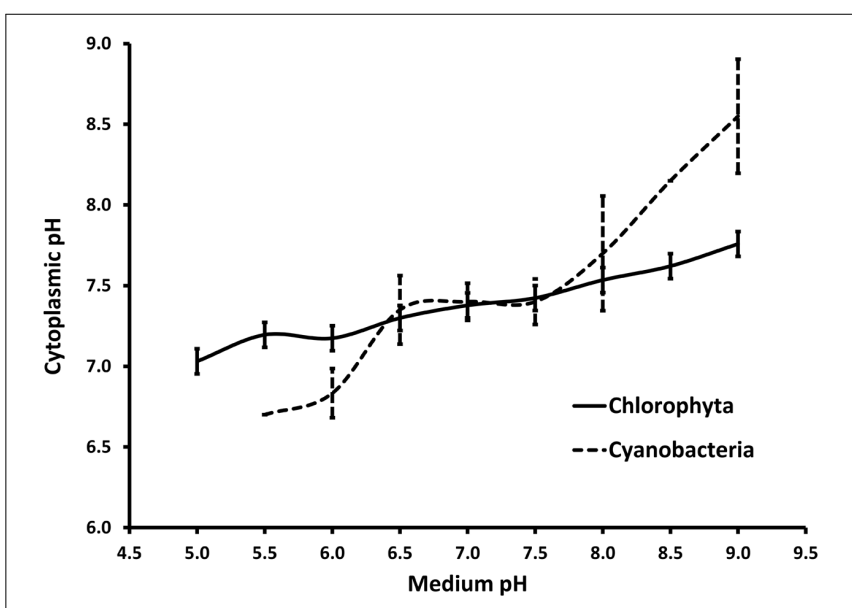

FIGURE 9 | Summary of cytoplasmic $\mathrm{pH}$ regulation in response to the $\mathrm{pH}$ in the surrounding media for members of phylum Chlorophyta and Cyanobacteria reported in the literature (seven and four members, respectively). Chlorophyta includes Chlorella kessleri (El-Ansari and Colman, 2015), Chlorella pyrenoidosa and Scenedesmus quadricauda (Lane and Burris, 1981), Chlorella saccharophila (Gehl and Colman, 1985), Chlorella vulgaris and Chlorella fusca (Küsel et al., 1990) and Dunaliella parva (Gimmler et al., 1988). Cyanobacteria include Agmenellum quadruplicatum and Gloeobacter violaceus (Belkin et al., 1987), Anacystis nidulans, (Falkner and Horner, 1976) and Synechococcus sp. (Kallas and Castenholz, 1982). Note that only one Cyanobacterium (A. quadruplicatrum) did grow at a $\mathrm{pH}$ below 6.0. All other data points are expressed as mean values with error bars representing 1 standard deviation. 
via 16s rRNA sequencing (Figures 1 and 2), qPCR was relied upon for advanced warning of a culture crash via increasing $V$. chlorellavorous abundance (Figure 7C). In general, detection of $V$. chlorellavorous via qPCR preceded visual observations of an impending crash, including an increase in the percent of Chlorella cells with attached bacteria ( $>20 \%$; Figures $6 \mathbf{B}$ and 7B), algal cell clumping and the culture changing color from dark green to yellowish brown (Figure 5). The analytical techniques developed and utilized here (i.e., V. chlorellavorus-specific qPCR assay, \% bacterial attachment to Chlorella cells) proved important for determining timing and success of treatment applications.

Although largely unaccounted for in the literature, $V$. chlorellavorus is known as a devastating predator of Chlorella. We have experienced first-hand how this cyanobacterium can induce culture crashes in a matter of days. Likewise, other Chlorella ponds in the southwestern USA have suffered similar crises from this predator (personal communication from Drs. P. Lammers, J. Brown, and M. Sommerfeld). Molecular reports available in the NCBI GenBank database suggest that this predator is widespread globally and therefore could potentially affect Chlorella cultures regardless of their location. In this context, the development of a treatment against $V$. chlorellavorus is especially significant because (1) there was no treatment available prior and (2) Chlorella-like microalgae are among the most commonly produced crops by the industry. In addition, the treatment was opportunistically validated in outdoor mixotrophic cultures, which are one order of magnitude more productive than traditional photoautotrophic cultures (Ganuza et al., 2015; Ganuza and Tonkovich, 2016, U.S. Patent No 2015/0118735 A1).

The crop protection strategy demonstrated here is straightforward and can be inexpensively applied at commercial scale ( $\sim$ USD $\$ 100$ for a $130,000 \mathrm{~L}$ reactor). The treatment has a low risk of failure given the broad tolerance of Chlorella to low $\mathrm{pH}$. The $\mathrm{pH}$-shock is highly selective against prokaryotes, as illustrated by the two log decrease in the total aerobic counts. Indeed, green microalgae (Chlorophyta) are better prepared than cyanobacteria to regulate internal $\mathrm{pH}$ relative to low external $\mathrm{pH}$ (relevant studies are summarized in Figure 9). Previously, the use of $\mathrm{pH}$-shock treatment has been used to control lactic acid bacterial contamination from anaerobic yeast cultures in the Brazilian bioethanol industry (Basso et al., 2011). In microalgae, the transition to moderately low $\mathrm{pH}$ (6) has been used to control diatoms (Zmora and Richmond, 2004), while the transition to high $\mathrm{pH}(9-10)$ has been used to promote the

\section{REFERENCES}

Altschul, S. F., Gish, W., Miller, W., Myers, E. W., and Lipman, D. J. (1990). Basic local alignment search tool. J. Mol. Biol. 215, 403-410. doi: 10.1016/S00222836(05)80360-2

Basso, L., Basso, T., and Rocha, S. (2011). "Ethanol production in Brazil: The industrial process and its impact on yeast fermentation," in Biofuel ProductionRecent Developments and Pospects, ed. M. A. S. Bernardes (Rijeka: InTech Open Access Publisher), 85-100.

Bates, L., Maechler, M., Bolker, B., and Walker, S. (2015). Fitting linear mixedeffects models using lme4. J. Stat. Softw. 67, 1-48. doi: 10.18637/jss.v067.i01 growth of cyanobacteria over green microalgae (Vonshak et al., 1983; Touloupakis et al., 2015). Because the $\mathrm{pH}$-shock treatment against $V$. chlorellavorus is applied for a discrete amount of time (15 min), resistance is less likely to develop than if applied continuously to the culture. To date, there is no indication that $V$. chlorellavorus has developed a tolerance to the treatment in our growth systems.

Successful rescue of actively infected algae culture heading for a crash is typically rare and attempts to circumvent a crash generally end in total loss when the culture is discarded. Total culture losses due to infections can greatly impact productivity, not to mention provide ample pathways to infect other ponds in the area during operation and take-down (reviewed by Carney and Lane, 2014; White and Ryan, 2015). The pH-shock treatment we have described here is capable of completely reversing high infection rates ( $>70 \%$ attachment) of a predatory bacterium, doubling Chlorella culture longevity and increasing the total harvested biomass from a commercial scale production platform. This treatment is now a routine component of our company mixotrophic operation.

\section{AUTHOR CONTRIBUTIONS}

EG and EL studied and reviewed the $\mathrm{pH}$ regulation in microalgae. EG and CS planned, designed, acquired, analyzed, and interpreted the data leading to the $\mathrm{pH}$ treatment development. $\mathrm{LC}$ and $\mathrm{BB}$ developed molecular assays and analyzed and interpreted the molecular data leading to the identification and monitoring of $V$. chlorellavorus. All authors drafted, read, critically revised and approved the final manuscript.

\section{ACKNOWLEDGMENTS}

We would like to thank the GP2 team (M. Lamont, A. Sitek, J. Lloyd-Randolfi, K. Boyd, B. Alderson, S. Ventre, R. Vannela, and L. Cizek) for helping to develop our mixotrophic platform, K. Sorensen for assistance with molecular work, J. Kniep for pushing the patenting process leading to the publishing of this paper, $\mathrm{S}$. Qin and J. Wilkenfeld for monitoring our cultures, Dr. Gherardi for his advice on statistics, the two anonymous reviewers for their helpful comments/suggestions and B. Melkonian and M. Melkonian for the molecular work on HS26. Lastly, we would like to thank R. A. Andersen for his microscopy work and his invaluable suggestions that greatly improved this manuscript.

Beijerinck, M. (1890). Kulturversuche mit Zoochlorellen, Lichenengonidien und anderen niederen Algen. Bot. Ztg. 48, 729.

Belkin, S., Mehlhorn, R. J., and Packer, L. (1987). Proton gradients in intact cyanobacteria. Plant Physiol. 84, 25-30. doi: 10.1104/pp. 84.1.25

Carney, L. T., and Lane, T. W. (2014). Parasites in algae mass culture. Front. Microbiol. 5:278. doi: 10.3389/fmicb.2014.00278

Carney, L. T., McBride, R. C., Smith, V. H., and Lane, T. W. (2016). "Molecular diagnostic solutions in algal cultivation systems," in Micro-Algal Production for Biomass and High-Value Products, eds S. P. Slocombe and J. R. Benemann (Boca Raton, FL: CRC Press). 
Carney, L. T., Reinsch, S. S., Lane, P. D., Solberg, O. D., Jansen, L. S., Williams, K. P., et al. (2014). Microbiome analysis of a microalgal mass culture growing in municipal wastewater in a prototype OMEGA photobioreactor. Algal Res. 4, 52-61. doi: 10.1016/j.algal.2013. 11.006

Carney, L. T., and Sorensen, K. (2015). Methods for Treating a Culture of Haematococcus pluvialis for Contamination Using Hydrogen Peroxide. U.S. Patent No 9,113,607. Washington, DC: U.S. Patent and Trademark Office.

Chelius, M. K., and Triplett, E. W. (2001). The diversity of archaea and bacteria in association with the roots of Zea mays L. Microb. Ecol. 41, 252-263. doi: $10.1007 / \mathrm{s} 002480000087$

Coder, D., and Goff, L. (1986). The host range of the chlorellavorus bacterium ("Vampirovibrio chlorellavorus"). J. Phycol. 46, 543-547. doi: 10.1111/j.15298817.1986.tb02499.x

Coder, D. M., and Starr, M. P. (1978). Antagonistic association of the chlorellavorus bacterium ("Bdellovibrio" chlorellavorus) with Chlorella vulgaris. Curr. Microbiol. 1, 59-64. doi: 10.1007/BF02601710

Das, K. C., Paul, S. S., Sahoo, L., Baruah, K. K., Subudhi, P. K., Ltu, K., et al. (2014). Bacterial diversity in the rumen of mithun (Bos frontalis) fed on mixed tree leaves and rice straw based diet. Afr. J Microbiol. Res. 8, 1426-1433. doi: 10.5897/AJMR2013.6507

El-Ansari, O., and Colman, B. (2015). Inorganic carbon acquisition in the acid-tolerant alga Chlorella kessleri. Physiol. Plant. 153, 175-182. doi: $10.1111 / \mathrm{ppl} .12228$

Falkner, G., and Horner, F. (1976). pH Changes in the Cytoplasm of the Blue-Green Alga Anacystis nidulans Caused by Light-dependent Proton Flux into the Thylakoid Space. Plant Physiol. 58, 717-718. doi: 10.1104/pp.58. 6.717

Ganuza, E., and Tonkovich, A. L. (2015). Method of Treating Bacterial Contamination in a Microalgae Culture with pH shock. U.S. Patent No 9,181,523. Washington, DC: U.S. Patent and Trademark Office.

Ganuza, E., and Tonkovich, A. L. (2016). "Heliae Development, LLC: an industrial approach to mixotrophy in microalgae," in Industrial biorenewables: a practical viewpoint, ed. P. Dominguez de Maria (New York, NY: Wiley), 616.

Ganuza, E., Tonkovich, A. L., and Licamele, J. D. (2015). Method of Culturing Microorganisms in Non-Axenic Mixotrophic Conditions. 41. U.S. Patent No 2015/0118735 A1. Washington, DC: U.S. Patent and Trademark Office.

Gehl, K. A., and Colman, B. (1985). Effect of external pH on the internal pH of Chlorella saccharophila. Plant Physiol. 77, 917-921. doi: 10.1104/pp.77. 4.917

Germond, A., Hata, H., Fujikawa, Y., and Nakajima, T. (2013). The phylogenetic position and phenotypic changes of a chlorella-like alga during 5-year microcosm culture. Eur. J. Phycol. 48, 485-496. doi: 10.1080/09670262.2013.860482

Gimmler, H., Kugel, H., Leibfritz, D., and Mayer, A. (1988). Cytoplasmic pH of Dunaliella parva and Dunaliella acidophila as monitored by in vivo ${ }^{31}$ P-NMR spectroscopy and the DMO method. Physiol. Plant. 74, 521-530. doi: 10.1111/j.1399-3054.1988.tb02013.x

Gong, Y., Patterson, D. J., Li, Y., Hu, Z., Sommerfeld, M., Chen, Y., et al. (2015). Vernalophrys algivore gen. nov., sp. nov. (Rhizaria: Cercozoa: Vampyrellida), a new algal predator isolated from outdoor mass culture of Scenedesmus dimorphus. Appl. Environ. Microbiol. 81, 3900-3913. doi: 10.1128/AEM. 00160-15

Gromov, B. V., and Mamkaeva, K. A. (1972). Electron microscopic study of parasitism by Bdellovibrio chlorellavorus bacteria on cells of the green alga Chlorella vulgaris. Tsitologiia 14, 256-260.

Guerrero, R., Pedros-Alio, C., Esteve, I., Mas, J., Chase, D., and Margulis, L. (1986). Predatory prokaryotes: predation and primary consumption evolved in bacteria. Proc. Natl. Acad. Sci. U.S.A. 83, 2138-2142. doi: 10.1073/pnas.83.7.2138

Holmberg, A., Blomstergren, A., Nord, O., Lukacs, M., Lundeberg, J., and Uhlén, M. (2005). The biotin-Streptavidin interaction can be reversibly broken using water at elevated temperatures. Electrophoresis 26, 501-510. doi: 10.1002/elps.200410070

Hoshina, R., and Fujiwara, Y. (2013). Molecular characterization of chlorella cultures of the national institute for environmental studies culture collection with description of Micractinium inermum sp. nov., Didymogenes sphaerica sp. nov., and Didymogenes soliella sp. nov. (Chlorellaceae, Trebouxiphyceae). Phycol. Res. 61, 124-132.

Kallas, T., and Castenholz, R. W. (1982). Rapid transient growth at low $\mathrm{pH}$ in the cyanobacterium Synechococcus sp. J. Bacteriol. 149, 237-246.

Küsel, A. C., Sianoudis, J., Leibfritz, D., Grimme, L. H., and Mayer, A. (1990). The dependence of the cytoplasmic $\mathrm{pH}$ in aerobic and anaerobic cells of the green algae Chlorella fusca and Chlorella vulgaris on the $\mathrm{pH}$ of the medium as determined by ${ }^{31} \mathrm{P}$ in vivo NMR spectroscopy. Arch. Microbiol. 153, 254-258. doi: 10.1007/BF00 249077

Lane, A. E., and Burris, J. E. (1981). Effects of environmental pH on the internal $\mathrm{pH}$ of Chlorella pyrenoidosa, Scenedesmus quadricauda, and Euglena mutabilis. Plant Physiol. 68, 439-442. doi: 10.1104/pp.68.2.439

Mamkaeva, K. A., and Rybal'chenko, O. V. (1979). Ultrastructural characteristics of Bdellovibrio chlorellavorus. Mikrobiologiia 48, $159-161$.

Marin, B. (2012). Nested in the chlorellales or independent class? Phylogeny and classification of the Pedinophyceae (Viridiplantae) revealed by molecular phylogenetic analyses of complete nuclear and plastidencoded rRNA operons. Protist 163, 778-805. doi: 10.1016/j.protis.2011. 11.004

Marin, B., Palm, A., Klingberg, M., and Melkonian, M. (2003). Phylogeny and taxonomic revision of plastid-containing euglenophytes based on SSU rDNA sequence comparisons and synapomorphic signatures in the SSU rRNA secondary structure. Protist. 154, 99-145. doi: 10.1078/143446103764928521

McBride, R. C., Lopez, S., Meenach, C., Burnett, M., Lee, P. A., Nohilly, F., et al. (2014). Contamination management in low cost open algae ponds for biofuels production. Ind. Biotechnol. 10, 221-227. doi: 10.1089/ind. 2013.1614

McBride, R. C., Smith, V. H., Carney, L. T., and Lane, W. T. (2016). "Crop protection in open ponds," in Micro-Algal Production for Biomass and HighValue Products, eds S. P. Slocombe and J. R. Benemann (Boca Raton, FL: CRC Press).

McMurdie, P. J., and Holmes, S. (2013). Phyloseq: an R package for reproducible interactive analysis and graphics of microbiome census data. PLoS ONE 8:e61217. doi: 10.1371/journal.pone.0061217

Pruesse, E., Peplies, J., and Glöckner, F. O. (2012). SINA: accurate high-throughput multiple sequence alignment of ribosomal RNA genes. Bioinformatics 28, 18231829. doi: 10.1093/bioinformatics/bts 252

R Core Team (2016). R: Language and Enviroment for Statistical Computing. Vienna: R Foundation for Statistical Computing. Available at: http://www.Rproject.org/

Rego, D., Redondo, L. M., Geraldes, V., Costa, L., Navalho, J., and Pereira, M. T. (2015). Control of predators in industrial scale microalgae cultures with Pulsed Electric Fields. Bioelectrochemistry 103, 60-64. doi: 10.1016/j.bioelechem.2014.08.004

Safi, C., Zebib, B., Merah, O., Pontalier, P.-Y., and Vaca-Garcia, C. (2014). Morphology, composition, production, processing and applications of Chlorella vulgaris: a review. Renew. Sustain. Energy Rev. 35, 265-278. doi: 10.1016/j.rser.2014.04.007

Shi, C., Wang, C., Xu, X., Huang, B., Wu, L., and Yang, D. (2015). Comparison of bacterial communities in soil between nematode-infected and nematodeuninfected Pinus massoniana pinewood forest. Appl. Soil Ecol. 85, 11-20. doi: 10.1016/j.apsoil.2014.08.008

Soo, R. M., Skennerton, C. T., Sekiguchi, Y., Imelfort, M., Paech, S. J., Dennis, P. G., et al. (2014). An expanded genomic representation of the phylum Cyanobacteria. Genome Biol. Evol. 6, 1031-1045. doi: 10.1093/gbe/evu073

Soo, R. M., Woodcroft, B. J., Parks, D. H., Tyson, G. W., and Hugenholtz, P. (2015). Back from the dead; the curious tale of the predatory cyanobacterium Vampirovibrio chlorellavorus. PeerJ. 3:e968. doi: 10.7717/peerj.968

Tonkovich, A. L., Ganuza, E., Licamele, J. D., Galvez, A., Sullivan, T. J., Adame, T., et al. (2014). Large Scale Mixotrophic Systems. WO. Patent No 2014/144270 A1. Geneva: World Intellectual property Organization.

Touloupakis, E., Cicchi, B., Benavides, A. M. S., and Torzillo, G. (2015). Effect of high pH on growth of Synechocystis sp. PCC 6803 cultures and their contamination by golden algae (Poterioochromonas sp.). Appl. Microbiol. Biotechnol. 100, 1333-1341. 
Vonshak, A., Boussiba, S., Abeliovich, A., and Richmond, A. (1983). Production of Spirulina biomass: maintenance of monoalgal culture outdoors. Biotechnol. Bioeng. 25, 341-349.

White, R. L., and Ryan, R. A. (2015). Long-term cultivation of algae in openraceway ponds: messons from the field. Ind. Biotechol. 11, 213-220. doi: 10.1089/ind.2015.0006

Wong, A. L. C., Beebee, T. J. C., and Griffiths, R. A. (1994). Factors affecting the distribution and abundance of an unpigmented heterotrophic alga Prototheca richardsi. Freshw. Biol. 32, 33-38. doi: 10.1111/j.1365-2427.1994.tb 00863.x

Zmora, O., and Richmond, A. (2004). "Microalgae for aquaculture: microalgae production for aquaculture," in Handbook of Microalgal Culture, ed. A. Richmond (Oxford: Blackwell Publishing Ltd), 365-379.
Conflict of Interest Statement: The authors declare that the research was conducted in the absence of any commercial or financial relationships that could be construed as a potential conflict of interest.

Heliae holds patents relevant to this work, all of which have been cited in this article.

Copyright (C) 2016 Ganuza, Sellers, Bennett, Lyons and Carney. This is an open-access article distributed under the terms of the Creative Commons Attribution License (CC BY). The use, distribution or reproduction in other forums is permitted, provided the original author(s) or licensor are credited and that the original publication in this journal is cited, in accordance with accepted academic practice. No use, distribution or reproduction is permitted which does not comply with these terms. 